\title{
Analysis of root canal organic tissue dissolution capacity according to the type of irrigation solution and agitation technique
}

\author{
Kiany Scarssi Nunes ${ }^{1}$, Letícia Feron', Francisco Montagner², Tiago André Fontoura de Melo \\ ${ }^{1}$ Faculdade da Serra Gaúcha - FSG, Dental School, Department of Clinical, Caxias do Sul, RS, Brazil \\ 2Universidade Federal do Rio Grande do Sul - UFRGS, Dental School, Department of Conservative Dentistry, Porto Alegre, RS, Brazil
}

Abstract

Aim: To analyze the root canal organic tissue dissolution capacity promoted by irrigating solutions, with or without the use of different agitation techniques. Methods: Bovine pulp tissue fragments were initially weighed. The following irrigating solutions were tested: $2.5 \%$ sodium hypochlorite, $2 \%$ chlorhexidine digluconate solution, and distilled water. The irrigating protocols were: immersion, mechanical agitation with endodontic files, and ultrasonic or sonic systems (Endoactivactor and Easy Clean $\odot)$. At the end of the protocols, the pulps were weighed to determine their final weight. For comparison, the average percentage of tissue dissolution in relation to the groups was analyzed using the Kruskal-Wallis nonparametric test complemented by multiple comparisons test. The significance level was set at $5 \%$. Results: Among the irrigation solutions, $2.5 \%$ sodium hypochlorite showed a higher dissolving power than $2 \%$ chlorhexidine digluconate and distilled water. Furthermore, ultrasonic and sonic systems were more effective irrigating protocols than immersion and mechanical agitation with endodontic files. Conclusions: The combination of sodium hypochlorite with an agitation system promotes a greater degree of tissue degradation.

Keywords: Endodontics. Dissolution. Sodium Hypochlorite. Chlorhexidine. Vibration.

\section{Introduction}

Because of the anatomical complexity of the root canal system, approximately $50 \%$ of the root canal walls remain untouched by instruments during preparation, which results in insufficient cleaning ${ }^{1}$. Necrotic tissue debris may provide a nutrient source for the surviving bacteria ${ }^{2}$.

Sodium hypochlorite is widely used to irrigate the root canal during endodontic procedures; its properties are low surface tension, antimicrobial capacity ${ }^{3}$, and ability to dissolve organic tissue ${ }^{4}$. However, because of its harmful action on periapical

Received for publication: August 05, 2016 Accepted: August 25, 2016

Correspondence to: Tiago André Fontoura de Melo Curso de Odontologia - Faculdade da Serra Gaúcha - FSG

Rua Os Dezoito do Forte, 2366 - São Pelegrino CEP 95020-472 - Caxias do Sul/RS - Brazil Phone: +55 5421016000 E-mail: tafmelo@gmail.com tissues and its cytotoxicity ${ }^{5}$, other substances have been used as alternatives, such as chlorhexidine digluconate. Chlorhexidine has antimicrobial properties, power of substantivity, and is less harmful to vital tissues compared with sodium hypochlorite ${ }^{6}$.

Many studies have reported the significant influence of a variety of factors such as concentration, time, temperature, contact area of tissue irrigation, and mechanical action of the irrigation process on tissue dissolution ${ }^{7,8}$. Currently, there have several resources to assist in the agitation process of an irrigating solution in the root canal. Sonic and ultrasonic systems with different tips and inserts and with different protocols have been tested. Unlike ultrasonic systems, which function at a high frequency and with a range of inserts for different areas of dentistry and with very well-defined 
purposes, the sonic systems such as the Endoactivator ${ }^{\circledR}($ Dentsply/ Maillefer, Ballaigues, Switzerland) and Easy Clean ${ }^{\circledR}$ (Easy Equipamento Odontológicos, Belo Horizonte, MG, Brazil) provide a specific mechanism of action and applicability for its use in the endodontic irrigation process. The tips of these two devices are flexible and have a small caliber in all extensions, which helps improve the action of the irrigation solution in areas of difficult access inside the root canal.

The aim of this study was to analyze the dissolution capacity of pulp tissue according to the type of the irrigating solution and the agitation technique employed in the chemical protocol of endodontic instrumentation.

\section{Material and methods}

Overall, 150 fragments of bovine pulp tissue, obtained from extracted mandibular central incisors, with an initial mean weight of $3.5 \pm 0.5 \mathrm{mg}$, were selected and divided into 15 experimental groups (Table 1).

Table 1 - Experimental groups.

\begin{tabular}{cccc}
\hline $\begin{array}{c}\text { Experimental } \\
\text { Group }\end{array}$ & $\mathrm{n}$ & Irrigation Solution & Agitation Protocol \\
G1 & 10 & Distilled Water & Immersion \\
G2 & 10 & Distilled Water & Mechanical Agitation \\
G3 & 10 & Distilled Water & Sonic System (Easy Endo ${ }^{\circledR}$ ) \\
G4 & 10 & Distilled Water & Sonic System (Endoactivactor ${ }^{\circledR}$ ) \\
G5 & 10 & Distilled Water & Ultrasonic System \\
G6 & 10 & $2.5 \%$ Sodium Hypochlorite & Immersion \\
G7 & 10 & $2.5 \%$ Sodium Hypochlorite & Mechanical Agitation \\
G8 & 10 & $2.5 \%$ Sodium Hypochlorite & Sonic System (Easy Endo ${ }^{\circledR}$ ) \\
G9 & 10 & $2.5 \%$ Sodium Hypochlorite & Sonic System (Endoactivactor ${ }^{\circledR}$ ) \\
G10 & 10 & $2.5 \%$ Sodium Hypochlorite & Ultrasonic System \\
G11 & 10 & $2 \%$ Chlorhexidine Digluconate & Immersion \\
G12 & 10 & $2 \%$ Chlorhexidine Digluconate & Mechanical Agitation \\
G13 & 10 & $2 \%$ Chlorhexidine Digluconate & Sonic System (Easy Endo ${ }^{\circledR}$ ) \\
G14 & 10 & $2 \%$ Chlorhexidine Digluconate & Sonic System (Endoactivactor ${ }^{\circledR}$ ) \\
G15 & 10 & $2 \%$ Chlorhexidine Digluconate & Ultrasonic System \\
\hline
\end{tabular}

The irrigating solutions used were $2.5 \%$ sodium hypochlorite (Bellafarma Farmácia de Manipulação, Caxias do Sul, RS, Brazil), 2\% digluconate chlorhexidine (Bellafarma Farmácia de Manipulação, Caxias do Sul, RS, Brazil), and distilled water (Iodontosul - Industrial Odontológica do Sul Ltda., Porto Alegre, RS, Brazil) as control. The type of agitation protocols included mechanical with endodontic files, ultrasonic system, and sonic systems (Endoactivator ${ }^{\circledR}$ and Easy $\mathrm{Clean}^{\circledR}$ ). The immersion of pulp tissue only in distilled water solution was used as the control group.

For the experiment, 10 bovine incisor roots were prepared to simulate the conditions of the pulp tissue within the root canal during the execution of the protocols, as reported in a recent study $^{9}$. Roots were standardized at $16 \mathrm{~mm}$ in length and the root canal was dilated to an equivalent of a number 4137 bur tip (KG Sorensen Indústria e Comércio Ltda., Barueri, SP, Brazil). The dental models were fixed on a metal tray with cyanoacrylate (Loctite, Hartford, CT, USA) to enable the solution agitation protocols.

In order to firm the pulp fragment in the apical third of the root canal, a surgical steel needle $0.20 \mathrm{~mm}$ in diameter was transfixed in the mesiodistal direction (Moxom Acupuncture, Budapest, Hungary) approximately $4 \mathrm{~mm}$ short of the apex (Figure 1). Initially, the pulp fragment was weighed on an electronic scale (Exacta Série Basic/ BL-1200AS, Curitiba, PR, Brazil). Afterwards, the bovine tissue was fixed within the canal and the canal was filled with $3 \mathrm{~mL}$ of irrigation solution.

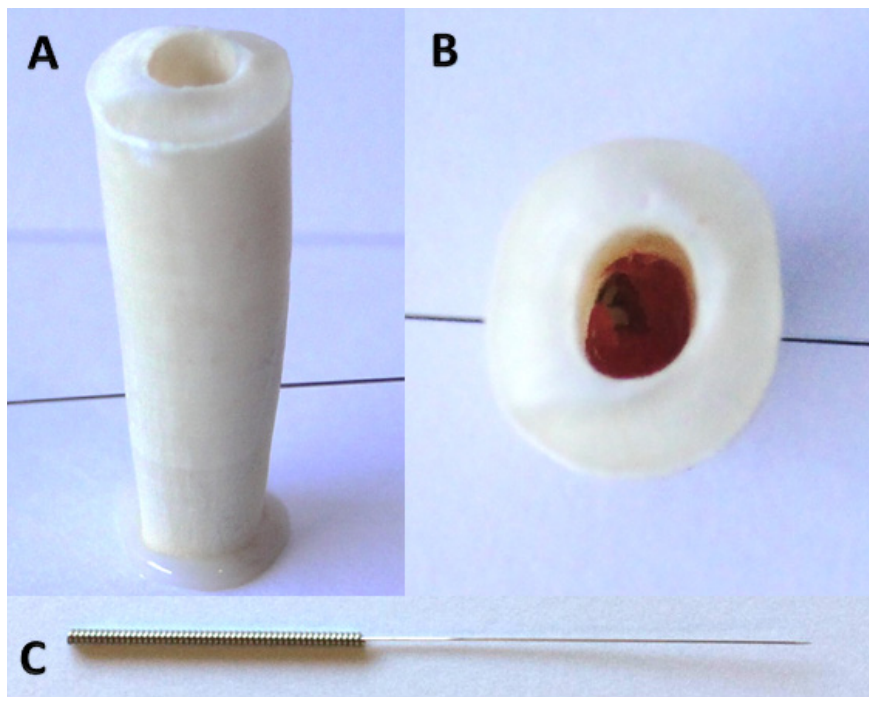

Fig.1. Image of pulp tissue fragment fixed inside the root canal: A (coronal view of the tooth), B (axial view of the tooth), and C (surgical steel needle).

Before the solution agitation protocol inside the root canal, the endodontic instrument for the manual-mechanical agitation and the sonic and ultrasonic tips were calibrated on $8 \mathrm{~mm}$ from the root edge.

For the immersion (control) group, there was no agitation protocol. The pulp tissue fragment remained immersed in the solution (distilled water) for $2 \mathrm{~min}$.

For the mechanical agitation with endodontic files, sonic (Endoactivator ${ }^{\circledR}$ and Easy Clean ${ }^{\circledR}$ ), and ultrasonic groups, the proposed protocol was to intersperse three immersing cycles of the pulp fragment inside the root canal containing irrigating solution (20 s) followed by agitation (20 s), totaling $2 \mathrm{~min}$, according to the protocol suggested by the systems manufacturers.

For mechanical agitation with endodontic files, an endodontic instrument type K file number 25 was used (Dentsply/ Maillefer). For the ultrasonic system, an insert GT40 was used (Gnatus Equipamentos Médico-Odontólogicos, Ribeirão Preto, SP, Brazil) and activated with an ultrasonic vibration of $50 \%$ potency of the Jet Sonic device 30,000 Hz (Dabi Atlante ${ }^{\circledR}$, São Paulo, SP, Brazil), without irrigation.

For the sonic systems Endoactivator ${ }^{\circledR}$ and Easy Clean ${ }^{\circledR}$, their respective flexible tips with diameters of 0.25 and 0.04 
taper were used. The Easy Clean ${ }^{\circledR}$ system was activated with the aid of a handpiece (KaVo in Brazil Industria e Comercio Ltda, Joinville, SP, Brazil) linked to a micromotor (KaVo in Brazil Industria e Comercio Ltda).

After completion of the agitation protocols associated with irrigating solutions, the pulp fragments were removed, dried with absorbent paper, and reweighed on a precision scale.

The $\mathrm{T}$ test was used to obtain the mean and standard deviation of the experimental groups. To compare the tissue dissolution capacity regarding the association of irrigating solutions and agitation protocols, the nonparametric KruskalWallis test was used, complemented by a multiple comparisons test. The significance level used in the study was set at $5 \%$.

\section{Results}

Table 2 shows the comparison between the initial and final weight for pulp tissue dissolution according to the type of the irrigant and agitation protocol. Regardless of the irrigating solution, the ultrasonic system and the sonic systems Endoactivator ${ }^{\circledR}$ and Easy Clean ${ }^{\circledR}$ differed significantly from immersion and mechanical agitation with endodontic files. In addition, there was a significant difference for mechanical agitation with endodontic files combined with $2.5 \%$ sodium hypochlorite.
Table 3 shows the comparison of the agitation protocols with each of the irrigating solutions. There was no significant difference in the tissue dissolution capacity between the irrigants in the immersion $(p=0.418)$ and mechanical agitation with endodontic files $(p=0.665)$. However, the use of ultrasonic system $(p=$ $0.041)$ and Endoactivator ${ }^{\circledR}(p=0.013)$ and Easy Clean ${ }^{\circledR}$ systems $(\mathrm{p}=0.040)$ resulted in a statistically significant difference. The combination of these devices with $2.5 \%$ sodium hypochlorite promoted greater dissolution capacity compared with the other two tested irrigators.

When comparing the solutions in relation to the agitation protocols (Table 4), it was observed that regardless of the irrigant, the use of sonic and ultrasonic systems promoted a greater capacity of tissue dissolution.

\section{Discussion}

Several studies ${ }^{10-12}$ have tested the outcomes of tissue dissolution during the process of endodontic irrigation. However, it is known that the capacity and efficiency of organic tissue degradation processes are related to the type, concentration, and quantity of irrigating, and how the solution is agitated ${ }^{7,8}$. Thus, this study aimed to analyze the capacity for tissue dissolution according to the combination of different types of irrigating solutions and agitation methods.

Table 2 - Comparison of irrigating solutions and agitation protocols as to the tissue dissolution capacity.

\begin{tabular}{|c|c|c|c|c|c|c|c|c|c|}
\hline \multirow{3}{*}{ Agitation protocol } & \multicolumn{9}{|c|}{ Irrigation Solution } \\
\hline & \multicolumn{3}{|c|}{ Distilled Water } & \multicolumn{3}{|c|}{$2 \%$ Chlorhexidine Digluconate } & \multicolumn{3}{|c|}{$2.5 \%$ Sodium Hypochlorite } \\
\hline & Initial Weight & Final Weight & $p$ & Initial Weight & Final Weight & $p$ & Initial Weight & Final Weight & $p$ \\
\hline Immersion & $0.033 \pm 0.015$ & $0.033 \pm 0.015$ & 1.000 & $0.029 \pm 0.011$ & $0.029 \pm 0.011$ & 1.000 & $0.039 \pm 0.017$ & $0.036 \pm 0.016$ & 0.081 \\
\hline Mechanical Agitation & $0.040 \pm 0.009$ & $0.037 \pm 0.011$ & 0.081 & $0.029 \pm 0.011$ & $0.026 \pm 0.009$ & 0.081 & $0.036 \pm 0.014$ & $0.031 \pm 0.011$ & 0.015 \\
\hline Ultrasonic System & $0.040 \pm 0.014$ & $0.035 \pm 0.014$ & 0.015 & $0.032 \pm 0.010$ & $0.027 \pm 0.011$ & 0.015 & $0.032 \pm 0.009$ & $0.018 \pm 0.009$ & 0.001 \\
\hline Endoactivactor ${ }^{\otimes}$ System & $0.040 \pm 0.010$ & $0.030 \pm 0.009$ & 0.008 & $0.039 \pm 0.011$ & $0.029 \pm 0.011$ & 0.008 & $0.039 \pm 0.015$ & $0.012 \pm 0.004$ & 0.001 \\
\hline Easy Clean ${ }^{\circledR}$ System & $0.032 \pm 0.009$ & $0.027 \pm 0.009$ & 0.015 & $0.031 \pm 0.007$ & $0.026 \pm 0.007$ & 0.015 & $0.037 \pm 0.017$ & $0.023 \pm 0.010$ & 0.001 \\
\hline
\end{tabular}

Table 3 - Average and medium ranks of the differences between the values of initial and final weight of the pulp fragments after the irrigation protocols.

\begin{tabular}{|c|c|c|c|c|c|}
\hline \multirow{3}{*}{ Agitation protocol } & & \multicolumn{3}{|c|}{ Irrigation Solution } & \multirow{3}{*}{$p$} \\
\hline & & \multirow{2}{*}{ Destilled Water } & $2 \%$ Chlorhexidine & $2.5 \%$ Sodium & \\
\hline & & & Digluconate & Hypochlorite & \\
\hline \multirow[t]{2}{*}{ Immersion } & Average (P25;P75) & $0.000(0.000 ; 0.000)$ & $0.000(0.000 ; 0.000)$ & $0.000(0.000 ; 0.010)$ & \multirow{2}{*}{0.418} \\
\hline & Rank Medium & $14.05^{\mathrm{A}}$ & $14.10^{\mathrm{A}}$ & $18.50^{\mathrm{A}}$ & \\
\hline \multirow[t]{2}{*}{ Mechanical Agitation } & Average (P25;P75) & $0.000(0.000 ; 0.010)$ & $0.000(0.000 ; 0.010)$ & $0.005(0.000 ; 0.010)$ & 0.665 \\
\hline & Rank Medium & $14.45^{\mathrm{A}}$ & $14.50^{A}$ & $17.50^{\mathrm{A}}$ & \\
\hline \multirow[t]{2}{*}{ Ultrasonic System } & Average (P25;P75) & $0.005(0.000 ; 0.010)$ & $0.005(0.000 ; 0.010)$ & $0.015(0.007 ; 0.020)$ & 0.041 \\
\hline & Rank Medium & $14.75^{\mathrm{B} /}$ & $14.50^{\mathrm{B}}$ & $21.00^{A}$ & \\
\hline \multirow[t]{2}{*}{ Endoactivactor System } & Average (P25;P75) & $0.010(0.000 ; 0.012)$ & $0.010(0.000 ; 0.012)$ & $0.020(0.010 ; 0.042)$ & 0.013 \\
\hline & Rank Medium & $12.30^{\mathrm{B}}$ & $12.40 \mathrm{~B}$ & $21.90 \mathrm{~A}$ & \\
\hline \multirow[t]{2}{*}{ Easy Clean ${ }^{\circledast}$ System } & Average (P25;P75) & $0.005(0.000 ; 0.011)$ & $0.005(0.000 ; 0.011)$ & $0.015(0.007 ; 0.020)$ & 0.040 \\
\hline & Rank Medium & $13.50^{\mathrm{B}}$ & $13.20^{B}$ & $21.10^{\mathrm{A}}$ & \\
\hline
\end{tabular}

Average followed by different capital letters in rows differ significantly by the nonparametric Kruskal-Wallis test, at a significance level of $5 \%$. 
Table 4 - Comparative analysis of the power to dissolve tissue of each irrigating solution for the different agitation protocols.

\begin{tabular}{lccc}
\hline \multirow{2}{*}{ Stirring Agitation } & \multicolumn{3}{c}{ Irrigation Solution } \\
\cline { 2 - 4 } & Destilled Water & $\begin{array}{c}2 \% \text { Chlorhexidine } \\
\text { Digluconate }\end{array}$ & $\begin{array}{c}2.5 \% \text { Sodium } \\
\text { Hypochlorite }\end{array}$ \\
Immersion & $15.4^{\mathrm{B}}$ & $15.5^{\mathrm{B}}$ & $13.5 \mathrm{C}$ \\
Mechanical Agitation & $22.7^{\mathrm{BC}}$ & $22.8^{\mathrm{BC}}$ & $16.8^{\mathrm{BC}}$ \\
Ultrasonic System & $27.3^{\mathrm{AB}}$ & $27.5^{\mathrm{AB}}$ & $29.4^{\mathrm{AB}}$ \\
Endoactivactor® System & $34.3^{\mathrm{AC}}$ & $346^{\mathrm{AC}}$ & $38.6^{\mathrm{A}}$ \\
Easy Clean® System & $27.5^{\mathrm{AB}}$ & $27.8^{\mathrm{AB}}$ & $30.2^{\mathrm{AB}}$ \\
\hline $\mathrm{p}$ & 0.013 & 0.015 & $<0.001$ \\
\hline
\end{tabular}

Average followed by different capital letters in columns differ significantly by the nonparametric Kruskal-Wallis test, at a significance level of $5 \%$.

Bovine pulp tissue fragments were used according to methods reported in recent studies ${ }^{13,14}$. The ease of obtaining and standardizing the length and weight of the pulp bovine tissue is an advantage because variation in these measures may influence the dissolution ability ${ }^{15}$. Bovine pulp tissue has been shown to be similar to the human pulp tissue ${ }^{2}$.

The delineation of an approximate initial weight of $0.03 \mathrm{~g}$ bovine tissue fragment is in agreement with the mass of the pulp tissue in a human molar tooth $(0.04 \mathrm{~mL} \times 1 \mathrm{~g} / \mathrm{mL}=0.04 \mathrm{~g})^{16}$.

In order to approximate this experiment to a more credible clinical condition, the dissolution capacity of the pulp tissue was measured within a tooth structure previously prepared for use, as previously reported in studies by Slutzky-Goldberg et al. ${ }^{17}$ (2013) and Arslan et al. ${ }^{18}$ (2015). Other studies ${ }^{13,14}$ used the same methodology, but immersed on a culture plate.

There are a variety of experimental methods for measuring the dissolution capacity, such as measuring the time of dissolution ${ }^{19}$ and visual examination ${ }^{12}$. In this study, the initial and final weights of the sample were compared, as reported in other studies ${ }^{4,14}$.

The definition and standardization of an experimental time of $2 \mathrm{~min}$ for each sample in all groups followed the manufacturers' recommendations for use of the Endoactivactor ${ }^{\circledR}$ and Easy Clean ${ }^{\circledR}$ systems.

Among the tested solutions, $2.5 \%$ sodium hypochlorite showed a higher tissue dissolution capacity than $2 \%$ chlorhexidine digluconate and distilled water, as reported elsewhere ${ }^{20}$ (1981). One of the known properties of sodium hypochlorite is its capacity of degradation organic tissue ${ }^{21}$.

On the other hand, chlorhexidine digluconate and distilled water showed no significant difference in their ability to dissolve tissue, and none of them was effective in the degradation of pulp tissue, which has been observed previously ${ }^{4,22}$. According to Marley et al. ${ }^{23}$ (2001), chlorhexidine digluconate has no solvent action on organic tissues, and neither does distilled water.

Regarding the agitation protocols, the combined use of sonic $\left(\right.$ Endoactivactor $^{\circledR}$ and Easy Clean ${ }^{\circledR}$ ) and ultrasonic systems with irrigating solution has been shown to increase the power to dissolve tissue, as seen in other studies ${ }^{24-26}$. In the present study, the power of tissue dissolution with the combination of these systems with chlorhexidine digluconate and distilled water was more efficient compared with the use of the immersion and mechanical agitation with endodontic files methods. It is believed that this result was possibly due to the direct action afforded by the vibration equipment: Ultrasound $(28.000 \mathrm{~Hz})$, Endoactivactor ${ }^{\circledR}(190 \mathrm{~Hz})$, and Easy Clean $^{\circledR}$ (approximately $4000 \mathrm{~Hz}$ ). Although at different frequencies, the similarity in results between the sonic and ultrasonic devices may have been provided by the small diameter of the tips used for operating the sonic devices. Both the Endoactivactor ${ }^{\circledR}$ and Easy Clean ${ }^{\circledR}$ systems have tips with a diameter of 0.25 and 0.04 taper. However, the ultrasonic insert used in this study has a pointed shape with initial diameter of 0.40 , which is therefore greater.

The fact that none of the protocols tested was fully effective in pulp tissue degradation can be associated with and justified by the agitation time used in the study. In a way, this condition may be of concern if we take into account faster preparations. However, it is believed that the process of agitation associated with the appropriate irrigating solution and not just the action of irrigating leverage the power of tissue dissolution. The repetition of several cycles of agitating the irrigating solution during chemomechanical preparation can promote the complete dissolution of the pulp tissue.

\section{References}

1. Peters OA, LaibA, Göhring TN, Barbakow F. Changes in root canal geometry after preparation assessed by high resolution computed tomography. J Endod. 2001 Jan;27(1):1-6.

2. Vera J, Siqueira JF Jr, Ricucci D, Loghin S, Fernández N, Flores B, et al. One-versus two-visit endodontic treatment of teeth with apical periodontitis: a histobacteriologic study. J Endod. 2012Aug;38(8):1040-52. doi: 10.1016/j. joen.2012.04.010.

3. Giardino L, Estrela C, Mohammadi Z, Palazzi F. Antibacterial power of sodium hypochlorite combined with surfactants and acetic acid. Braz Dent J. 2014;25(4):289-94.

4. Tartari T, Guimarães BM, Amoras LS, Duarte MA, Silva e Souza PA, Bramante CM. Etidronate causes minimal changes in the ability of sodium hypochlorite to dissolve organic matter. Int Endod J. 2015 Apr;48(4):399404. doi: 10.1111/iej.12329.

5. Mirhadi H, Abbaszadegan A, Ranjbar MA, Azar MR, Geramizadeh B, Torabi $S$, et al. Antibacterial and Toxic Effect of Hydrogen Peroxide Combined with Different Concentrations of Chlorhexidine in Comparison with Sodium Hypochlorite. J Dent (Shiraz). 2015 Dec;16(4):349-55.

6. Gomes BP, Vianna ME, Zaia AA, Almeida JF, Souza-Filho FJ, Ferraz CC. Chlorhexidine in endodontics. Braz Dent J. 2013;24(2):89-102. doi: 
10.1590/0103-6440201302188.

7. Clarkson RM, Moule AJ, Podlich H, Kellaway R, Macfarlane R, Lewis D, et al. Dissolution of porcine incisor pulps in sodium hypochlorite solutions of varying compositions andconcentrations. Aust Dent J. 2006 Sep;51(3):24551.

8. Del Carpio-Perochena AE, Bramante CM, Duarte MA, Cavenago BC, Villas-Boas MH, Graeff MS, et al. Biofilm dissolution and cleaning ability of different irrigant solutions on intraorally infected dentin. J Endod. 2011 Aug;37(8):1134-8. doi: 10.1016/j.joen.2011.04.013.

9. Andersen M, Lund A, Andreasen JO, Andreasen FM. In vitro solubility of human pulp tissue in calcium hydroxide and sodium hypochlorite. Endod Dent Traumatol. 1992 Jun;8(3):104-8.

10. Cobankara FK, Ozkan HB, Terlemez A. Comparison of organic tissue dissolution capacities of sodium hypochlorite and chlorine dioxide. J Endod. 2010 Feb;36(2):272-4. doi: 10.1016/j.joen.2009.10.027.

11. Stojicic S, Zivkovic S, Qian W, Zhang H, Haapasalo M. Tissue dissolution by sodium hypochlorite: effect of concentration, temperature, agitation, and surfactant. J Endod. 2010 Sep;36(9):1558-62. doi: 10.1016/j. joen.2010.06.021.

12. Taneja S, Mishra N, Malik S. Comparative evaluation of human pulp tissue dissolution by different concentrations of chlorine dioxide, calcium hypochlorite and sodium hypochlorite: An in vitro study. J Conserv Dent. 2014 Nov;17(6):541-5. doi: 10.4103/0972-0707.144590.

13. Irala LED, Soares RG, Salles AA, Munari AZ, Pereira JS. Dissolution of bovine pulp tissue in solutions consisting of varying $\mathrm{NaOCl}$ concentrations and combined with EDTA. Braz Oral Res. 2010 Jul-Sep;24(3):271-6.

14. Só MVR, Cemim A, Pereira EP, Irala LED. Tissue dissolution ability of sodium hypochlorite from different manufacturers. Braz Endod J. 2010 Sep;36(9):1558-62. doi: 10.1016/j.joen.2010.06.021.

15. Niewierowski RS, Scalzilli LR, Morgental RD, Figueiredo JA, Vier-Pelisser FV, Borba MG, et al. Bovine pulp tissue dissolution ability of irrigants associated or not to ultrasonic agitation. Braz Dent J. 2015 Oct;26(5):53740. doi: 10.1590/0103-6440201300243.
16. Morgan RW, Carnes DL Jr, Montgomery S. The solvent effects of calcium hydroxide irrigating solution on bovine pulp tissue. J Endod. 1991 Apr;17(4):165-8.

17. Slutzky-Goldberg I, Hanut A, Matalon S, Baev V, Slutzky H. The effect of dentin on the pulp tissue dissolution capacity of sodium hypochlorite and calcium hydroxide. J Endod. 2013 Aug;39(8):980-3. doi: 10.1016/j. joen.2013.04.040.

18. Arslan D, Guneser MB, Kustarci A, Er K, Siso SH. Pulp tissue dissolution capacity of QMix 2in1 irrigation solution. Eur J Dent. 2015 JulSep;9(3):423-7. doi: 10.4103/1305-7456.163229.

19. Johnson BR, Remeikis NA. Effective shelf-life of prepared sodium hypochlorite solution. J Endod. 1993 Jan;19(1):40-3.

20. Gordon TM, Damato D, Christner P. Solvent effect of various dilutions of sodium hypochlorite on vital and necrotic tissue. J Endod. 1981 Oct;7(10):466-9.

21. Estrela C, Estrela CR, Barbin EL, Spanó JC, Marchesan MA, Pécora JD. Mechanism of action of sodium hypochlorite. Braz Dent J. 2002;13(2):113-7.

22. Okino LA, Siqueira EL, Santos M, BombanaAC, Figueiredo JAP. Dissolution of pulp tissue by aqueous solution of chlorhexidine digluconate and chlorhexidine digluconate gel. Int Endod J. 2004 Jan;37(1):38-41.

23. Marley JT, Ferguson DB, Hartwell GR. Effects of chlorhexidine gluconate as an endodontic irrigant on the apical seal: short-term results. J Endod. 2001 Dec;27(12):775-8.

24. Sabins RA, Johnson JD, Hellstein JW. A comparison of the cleaning efficacy of short term sonic and ultrasonic passive irrigation after hand instrumentation in molar root canals. J Endod. 2003 Oct;29(10):674-8.

25. Paragliola R, Franco V, Fabiani C, Mazzoni A, Nato F, Tay FR, et al. Final rinse optimization: influence of different agitation protocols. J Endod. 2010 Feb;36(2):282-5. doi: 10.1016/j.joen.2009.10.004.

26. Haapasalo M, Wang Z, Shen Y, Curtis A, Patel P, Khakpour M. Tissue dissolution by a novel multisonic ultracleaning system and sodium hypochlorite. J Endod. 2014 Aug;40(8):1178-81. doi: 10.1016/j. joen.2013.12.029. 